\title{
The Call of Simon Peter in Luke 5:1-11: A Lukan Invention?
}

\author{
SŁAWOMIR SZKREDKA \\ Saint John's Seminary, Camarillo, CA, USA \\ e-mail: sszkredka@stjohnsem.edu \\ ORCID: 0000-0003-0311-1358
}

\begin{abstract}
Summary: Recent studies on the role of the eyewitnesses in the formation of the Gospel tradition argue for the singular importance of the original followers of Jesus. Luke himself might reflect their unique standing with his stated reliance on "the eyewitnesses and the servants of the word" (1:2). Still, Luke's expansion of the Markan call of Peter seems, to many modern scholars at least, precisely that - a literary reworking of the original Markan story. Luke thus appears to resort to literary fiction to confirm the authority of those who guarantee the non-fictional character of his narrative. The conflicting nature of this operation needs to be reexamined. As this article argues, the recent studies on the Lake of Galilee, Simon Peter, and the role of the eyewitnesses offer enough evidence to suggest that in composing the story of the call of Peter, Luke relied on a source that depicted the call in connection with the fishing miracle. Secondly, existence of such a tradition opens new possibilities for reconstructing the past so differently narrativized by Luke and Mark.
\end{abstract}

Keywords: Gospel of Luke, Call of Simon Peter, Historical Peter, Luke's Sources

\begin{abstract}
C ompared with its Markan counterpart, Luke's depiction of the call of Simon Peter in 5:1-11, is much more elaborate. ${ }^{1}$ It contains a fishing miracle and allows for a considerable amount of interaction between Jesus and his first disciple. There is a notable increase in the narrative attention dedicated to Peter in Lk 5:1-11. As the scene of his call intimates, and the rest of Luke-Acts makes clear, Peter is to become the principal eyewitness, proclaimer, and imitator of Jesus. Interestingly, recent studies on the role of the eyewitnesses in the formation of the Gospel tradition ${ }^{2}$ confirm the singular importance of the original
\end{abstract}

1 Throughout, we are assuming Markan priority and Luke's literary dependence on Mark.

2 There is a growing interest in the role eyewitnesses might have played in the formation of the gospel traditions. The works of S. Byrskog, Story as History. History as Story: The Gospel Tradition in the Context of Ancient Oral History (WUNT II 123; Tübingen: Mohr Siebeck 2000); J.D.G. Dunn, Jesus Remembered. Christianity in the Making (Grand Rapids, MI - Cambridge, U.K.: Eerdmans 2003); and R.J. Bauckham, Jesus and the Eyewitnesses: The Gospel as Eyewitness Testimony (Grand Rapids, MI - Cambridge, U.K.: Eerdmans 2006), have questioned the old form critical model and redirected scholarly attention to the notions of orality, eyewitness 
followers of Jesus. Luke himself might reflect it with his stated reliance on "the eyewitnesses and the servants of the word" (1:2). ${ }^{3}$ Still, Luke's expansion of the Markan call of Peter seems, to many modern scholars at least, precisely that - a literary reworking of the original Markan story. Luke thus appears to resort to literary fiction to confirm the authority of those who guarantee the non-fictional character of his narrative. The conflicting nature of this operation could simply result from the discrepancy between the modern and ancient norms of historiography: ancient historians would have felt more freedom to reshape their sources. ${ }^{4}$ The same contradiction, however, could also call for a fresh analysis of the Lukan redaction of Lk 5:1-11. Recent appreciation of the role of the eyewitnesses as well as the new studies on Peter ${ }^{5}$ in the New Testament

testimony, and memory. What lies at the heart of the debate concerning the role of eyewitnesses, is the relationship between the historical event (Jesus) and its interpretation (written Gospels). Are the Gospels a product of an anonymous oral transmission, a creative process of reshaping the stories in accord with the needs and sensitivities of diverse early Christian communities? Or, is the written form of the Gospels based on a reliable testimony of the eyewitnesses who both participated in the narrated events and from the beginning were responsible for their retelling? If the model of uncontrolled oral transmission effectively detaches the historical event (Jesus) from its later interpretation rendering the Gospels historically unreliable, the "eyewitness" model of Gospel formation appears to connect the historical event and its interpretation through the medium of human memory. How much reliability or unreliability can be ascribed to the powers of human memory continues to be debated [see J. Redman, "How Accurate Are Eyewitnesses? Bauckham and the Eyewitnesses in the Light of Psychological Research", JBL 129 (2010) 177-197; R.K. Mciver, "Eyewitnesses as Guarantors of the Accuracy of the Gospel Traditions in the Light of Psychological Research", JBL 131 (2012) 529-546]. More importantly, however, one must ask whether the category of "eyewitness testimony" can adequately account for the Gospels as linguistically and compositionally coherent narratives expressive of the literary strategies of their writers [cf. J. Schröter, "The Gospels as Eyewitness Testimony? A Critical Examination of Richard Bauckham's, Jesus and the Eyewitnesses", JSNT 31.2 (2008) 195-209, especially 208]. Still, the idea of the eyewitnesses as the guarantors of the Gospel's tradition, even if (or perhaps because) it must contend with the meanderings of the human memory and make room for the Gospel writers' literary sophistication, holds a hermeneutic potential that deserves to be explored.

3 One needs to remember that Luke's claim to rely on the received traditions is a highly conventional statement at the service of a clear rhetorical goal: to justify the fact that he retells again that which has already been reported before him. See D.D. Schmidt, "Rhetorical Influences and Genre: Luke's Preface", Jesus and the Heritage of Israel: Luke's Narrative Claim upon Israel's Legacy (ed. D.P. Moessner) (Harrisburg, PA: Trinity Press International 1999) 27-60. Still, the conventional character of Luke's claim does not necessarily invalidate its factuality.

4 As J. Grethlein - C.B. Krebs, "The Historian's Plupast: Introductory Remarks on Its Forms and Functions", Time and Narrative in Ancient Historiography: The 'Plupast' from Herodotus to Appian (ed. J. Grethlein - C.B. Krebs) (Cambridge: Cambridge University Press 2012) 8, aptly remark, "history was considered part of the rhetorical system and [...] the genre of historiography was pervasively influenced by rhetoric." N. Militsios, The Shaping of Narrative in Polybius (Berlin - Boston: Walter de Gruyter 2013) 4, passes the following judgment on ancient historians: "in their efforts to impose coherence and meaning on the events they describe, even the most scrupulous historians engage in various kinds of distortions, omission and embellishments."

5 T. Wiarda, Peter in the Gospels: Pattern, Personality, Relationship (WUNT II 123; Tübingen: Mohr Siebeck 2000); M. Hengel, Saint Peter: The Underestimated Apostle (transl. T.H. Trapp) 
offer enough new insights to justify a fresh examination of the possible sources behind Lk 5:1-11.

As this article shall argue, there is enough evidence to suggest that in composing the story of the call of Peter, Luke relied on a source that depicted the call in connection with the fishing miracle. Secondly, an existence of such a tradition allows for several historical reconstructions regarding Peter's transforming encounter with Jesus, diversely recounted by Mark and Luke. Working toward these conclusions, we begin with a preliminary step: we shall compare Lk 5:1-11 with its Markan counterpart delineating Luke's principal narrative interests, particularly his increased attention to Peter.

\section{The Call of Peter and Luke's Narrative Interests}

In the Markan version, Simon is called alongside his brother Andrew. The two are casting nets as Jesus' call to follow him and his promise to make them fishers of men pulls them out of their ordinary work and into his company. Two more brothers, James and John, are called immediately after and in similar circumstances (cf. Mk 1:16-20). Jesus' power to choose and attract followers, as well as the first followers' radical obedience to his call are on display. The Lukan equivalent of the same scene is different. It tells a more complex story and reflects diverse narrative interests.

The set-up of the story, created in Lk 5:1-3, departs from the Markan Vorlage. The place is identified as the shore of the Lake of Gennesaret, not the Sea of Galilee as in Mark; the personages are Jesus, the crowd that listens to him, and finally the fishermen, in particular Simon, in whose boat Jesus sits and teaches. The internal structure of this initial vignette is significant:

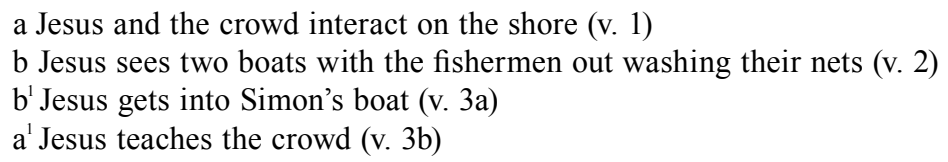

Firstly, the structure centers on the personages of Peter and his companions. Secondly, two elements become intertwined: the teaching of the word of God and the fishermen. These two elements will return by way of inclusion in verses

(Grand Rapids, MI: Eerdmans 2010) (German original 2006); M. Bockmuehl, The Remembered Peter: In Ancient Reception and Modern Debate (WUNT 262; Tübingen: Mohr Siebeck 2010); M. Bockmuehl, Simon Peter in Scripture and Memory (Grand Rapids, NI: Baker Academic 2012); H.K. Bond - L. W. Hurtado, eds., Peter in Early Christianity (Grand Rapids, MI: Eerdmans 2015). For an extensive bibliography see the two volumes by Bockmuehl. 
10b-11 where Peter and his companions step into their new identity: they are to be the ones "catching" people, mirroring what Jesus does in 5:1-3. Beginning with verse 4 , the crowd disappears, and the story centers exclusively on the interaction between Jesus, on the one hand, and Peter and his companions, on the other. Told by Jesus to lower the nets for a catch (5:4), Peter decides to act on Jesus' word and against his own experience. ${ }^{6}$ The outcome is a miraculous catch. Still, the miraculous abundance of fish is not simply an answer to the lack of fish resulting from a futile night of fishing. From the way the story progresses, its silence about what happened next to the abundant catch, it becomes clear that the real interest of the story is in the identities of its heroes. Peter's reaction in verse 8 expresses his new awareness of who Jesus is ("the Lord"), as well as his corresponding self-awareness ("a sinful man"). Finally, Jesus reveals to Peter and his companions who they are (10b) in relationship to him: from now they will be catching people. By leaving their boats behind and following Jesus they act out their new identity.

As it stands, Lk 5:1-11 advances some of Luke's principal narrative interests. As already mentioned, Luke's prologue (1:1-4) authenticates the forthcoming narrative by anchoring it in the accounts of the eyewitnesses. While the necessity of eyewitnesses' mediation betrays the historical distance between the Lukan community and the narrated events, it also speaks to the growing awareness of the normative value of eyewitnesses' account of these events. Luke and his community are not only interested in the events but also in the eyewitnesses that testify to them. Lk 5:1-11 meets that interest. ${ }^{7}$

Secondly, Luke's decision to postpone, against the Markan Vorlage, the call of the first disciples until after Jesus' programmatic appearance in the Nazareth-Capernaum diptych allows the reader to interpret the call of Simon in light of the main theme of Jesus' inaugural proclamation, that is, as the actualization of Jesus' ministry of release (ä $\phi \varepsilon \sigma ı s 4,18)$. Simon is set free from the fearful confines of his self-confessed sinfulness and for the participation in the ministry of Jesus. He becomes the model of many individuals who, having encountered Jesus, undergo transformation. Simon's unique ecclesiological position

6 See the observation by R.E. Brown, The Gospel According to John (XIII-XXI): Introduction, Translation, and Notes (AncB 29A; New York: Doubleday 1970) 1069: "those knowledgeable in Palestinian customs assert that on the Lake of Galilee night fishing is usually better than day fishing."

7 According to Hengel, Saint Peter, 80, "if Peter's student Mark serves as the most important of

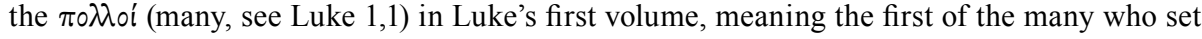
forth the story about Jesus as mentioned in Luke's prologue, then Peter is the leading figure for the auctor ad Theophilum - in fact, one might even say that he is purely and simply the paradigmatic figure in this regard among the 'eyewitnesses and ministers of the word' on behalf of those who came later." 
(the primary eyewitness) serves to highlight his universal anthropological profile (a self-confessed sinner). ${ }^{8}$

Finally, Luke's substitution of Mark's brief account of the call of the first disciples with the story of the miraculous catch generates the development of a strong parallel between the missionary activities of Jesus and of Peter depicted in the Gospel and in the Book of Acts respectively. Thus the authority of Peter as the primary eyewitness of the story of Jesus is reinforced by his role as the primary imitator of Jesus. The church addressed by Luke would find its own Gentile-mission origin as well as its subsequent missionary activity validated by the characterization of both Jesus and Peter as first missionaries. ${ }^{9}$

The story narrated by Luke in 5:1-11 fits well into the web of Lukan principal themes and theological interests. Is it because it was composed by Luke in the first place? Or is it because Luke decided to develop theological interest present in the tradition he inherited? It is to these questions that our analysis now turns.

\section{Sifting Through the Possible Sources Behind Lk 5:1-11}

The parallel scene in Mark 1:16-20, together with the material in Mark 3:7.9 and 4:1, which Luke omits in the corresponding parts of his narrative (6:17-18; 8:4), offer themselves as the most likely sources for the Lukan call of Peter. ${ }^{10}$ Secondly, a close thematic connection with John 21 suggests another possible source of influence, either direct or through a common tradition, behind Luke 5:1-11 and John 21. Sorting out the influences between Markan, Lukan, and Johannine accounts is a complicated matter. This complexity is reflected in a multiplicity of solutions proposed to account for the present shape of the Lukan version of the call of Peter and his companions. These solutions range from seeing the pericope as a literary product of Luke with Markan elements visible only in the exposition and the conclusion of the scene, ${ }^{11}$ through postulating two basic

8 He is the first among the many individuals named "sinners." On this peculiarly Lukan theme of sin and sinners, see D. Neale, None but the Sinners: Religious Categories in the Gospel of Luke (JSNT.S 58; Sheffield: Academic Press 1991); H. Adams, The Sinner in Luke (The Evangelical Theological Society Monograph Series; Eugene, OR: Pickwick 2008), and A. Pesonen, Luke, the Friend of Sinners (Diss. University of Helsinki; Helsinki 2009).

9 See D.J. Scholz, Luke 5:1-11: The Call and Commission of Simon Peter (Diss. Marquette University; Milwaukee, WI 1997) 5, for whom "Luke 5,1-11 is a critical episode in the story of Luke-Acts because it begins a process of informing the implied reader of the Gentile mission and inclusion in the early church, one of the text's governing norms and values."

10 One could also include among possible sources Mk 2,13, which mentions the lake but not the boat. Luke omits it in a corresponding passage in 5,27.

11 See, for instance, U. Busse, "Begegnung mit dem Wort nach Lk 5,1-11", Luke and his readers: Festschrift A. Denaux (ed. R. Bieringer - G. van Belle - J. Verheyden) (Leuven: Peeters 2005) 
combinations of sources (Mark and Luke's Sondergut) ${ }^{12}$, to claiming a special Lukan source behind the whole pericope. ${ }^{13}$ Let us proceed by weighing the degrees of probability between various possible solutions.

If we divide Luke 5:1-11 into three thematic parts (the teaching from a boat, the miraculous catch, and the call of Peter) and position them against Luke's most extensively used source, the Gospel of Mark, this simple juxtaposition of Luke and Mark reveals that the possible Markan influence can refer only to the first and to the last element of the Lukan story, that is, to the teaching from the boat (Mark 3:7.9 and 4:1) and the calling of Peter (Mark 1:16-20). Accordingly, it has been suggested to see 5:1-3 and 5:9b-11 as the Lukan redaction of Mark, while

120, who concludes that "die Perikope ein eindeutig literarisches Produkt des Evangelisten ist, der seine einzigen Anregungen den markinischen Vorlagen verdankt.” In a similar vein, though with less certitude, W. Eckey, Das Lukasevangelium unter Berücksichtigung seiner Parallelen. Teilband 1: Lk 1,1-10,42 (2. durchgesehene Auflage) (Neukirchen-Vluyn: Nuekirchener 2006) 242, having acknowledged Markan influence behind verses 1-3 and 10-11, states regarding verses 4-9: "Da die Sprache dieser Verse lukanisch und das erzählte Geschehen nicht von dem in den Versen 1-3.10-11 dargestellten ablösbar ist, besteht die Möglichkeit, daß Lukas die Erzählung selbst verfaßt hat."

12 Most commentators fall within this category. The first combination of sources, to which many scholars subscribe, is the Markan Vorlage underneath verses 1-3.10-11 and a special Lukan source behind the story of the miraculous catch of fish in 4-9. See R.E. Brown - K.P. Donfried - J. Reumann, eds., Peter in the New Testament: A Collaborative Assessment by Protestant and Roman Catholic Scholars (New York: Augsburg Publishing House 1973) 115; J.A. Fitzmyer, The Gospel According to Luke I-IX. Introduction, Translation, and Notes (AncB 28; New York: Doubleday 1981) 560-562; I.H. Marshall, The Gospel of Luke. A Commentary on the Greek Text (NIGTC; Grand Rapids, MI: Eerdmans 1978) 201; R. Pesch, Der reiche Fischfang: Lk 5,1-11/ Jo 21,1-14. Wundergeschichte-Berufungserzählung-Erscheinungsbericht (Kommentare und Beiträge zum Alten und Neuen Testament; Düsseldorf: Patmos 1969) 64-85; W. Radl, Das Evangelium nach Lukas. Kommentar. Erster Teil: 1,1-9,50 (Freiburg im Breisgau: Herder 2003) 293-294; G. Rossé, Il Vangelo di Luca. Commento esegetico e teologico (Collana scritturistica di Città Nuova; Roma: Città Nuova 1992) 171; L. Sabourin, L'Évangile de Luc. Introduction et commentaire (Roma: Pontificia Universitas Gregoriana 1985) 143-144; G. Schneider, Das Evangelium nach Lukas. Kapitel 1-10 (ÖTNT 3/1; Gütersloher - Würzburg: Gütersloher Verlagshaus 1977) 122. The second combination of sources claims the Lukan special source to have included both the miraculous catch (4-9) and the call (10b), leaving rest of the story to Luke's redacting of the Markan material. See S.O. Abogunrin, "The Three Variant Accounts of Peter's Call. A Critical and Theological Examination of the Texts", NTS 31 (1985) 594; D.L. Bock, Luke (BECNT; Grand Rapids, MI: Baker 1994) I, 451; F. Bovon, Luke 1: A Commentary on the Gospel of Luke 1:1-9:50 (transl. C. M. THOMAs) (Hermeneia; Minneapolis, MN: Fortress Press 2002) 167; J.L. Nolland, Luke 1-9:20 (WBC 35a; Dallas: Word Books 1989) 220; H. Schürmann, Das Lukasevangelium. I. Kommentar zu Kap. 1,1-9,50 (HThKNT 3; Freiburg: Herder 1969) 272-273; M. Wolter, Das Lukasevangelium (HNT 5; Tübingen: Mohr Siebeck 2008) 211 sees the miracle story as separate from the call but he does not exclude the possibility that "bereits die vorlk Erzählung vom überreichen Fischfang durch ein Jesuswort abgeschlossen wurde, mit dem Petrus in die Nachfolge oder zur Sendung berufen wurde."

13 See W. Dietrich, Das Petrusbild der Lukanischen Schriften (BWANT 94; Stuttgart: Verlag W. Kohlhammer 1972) 23-76. 
viewing 5:4-9a as the Lukan redaction of a miracle-story. ${ }^{14}$ The problem with this solution, as Nolland has rightly pointed out, ${ }^{15}$ is that it leaves unanswered Peter's request, "Depart from me, because I am a sinful man, Lord" (5:8). If like Moses and Isaiah before him, Peter is called through a gift of divine epiphany, then the epiphany realized through the miraculous catch and acknowledged by Peter's request (5:8) cannot simply stop without a resolution in the form of a call to serve God. Comparisons with Isaiah 6 and Exodus 3 counsel against postulating a hypothetical source with the miraculous catch and no calling attached to it. ${ }^{16}$

There are other factors in favor of the original connection between the epiphany and the call. The structural analysis of the whole pericope conducted by Delorme $^{17}$ uncovers the presence of three parallel sequences of actions in vv. 4-6, v. 7, and vv. 8-11. The first sequence consists of Jesus' order (4), Peter's objection (5a), Peter's acceptance of the order (5b), and the fulfillment of the order (6). This sequence is parallel to the call for help (7a), acceptance of the call (7b), execution of help (7c), which in turn is paralleled by the order of Peter (8b), Jesus' annulment of that order (10b), Peter's execution of that annulment (11). Three sequences, where in the first and the last the command is separated from its execution by a tension-heightening complication, create a fairly unified structure, at least for 5:4-11. ${ }^{18}$ It follows that if we are to respect the connection between the epiphany and the call we should either postulate a source, which contains such a connection, or opt for a Lukan composition, which creates it.

The arguments for Luke's literary production come from stylistic considerations. The language of the pericope bears clear marks of Lukan reworking. Lukan diction is discernible in almost every verse of the story. ${ }^{19}$ Thus, some scholars

14 See Fitzmyer, Luke, I, 560.

15 Nolland, Luke, I, 220.

16 Y. Mathieu, La figure de Pierre dans l'oeuvre de Luc. (Évangile et Actes des Apôtres) une approche synchronique (Études Bibliques. Nouvelle Série, 052; Paris: Gabalda 2004) 68, seconds Nolland's judgment when he identifies the form of the story as the Old Testament inspired Lukan vocation story.

17 J. Delorme, "Luc 5,1-11: analyse structurale et histoire de la redaction", NTS 18 (1972) 336-337.

18 Which is not to say that there are no structural correlations between 1-3 and 4-11. They are of a different order. Delorme points out spatial correlations and, naturally, personages, which bind 1-3 with 4-11. See Delorme, "Luc 5,1-11", 338-343.

19 The following words and constructions have been identified as characteristic of Luke by either A. Denaux - R. Corstjens, The Vocabulary of Luke: An Alphabetical Presentation and a Survey of Characteristic and Noteworthy Words and Word Groups in Luke's Gospel (Leuven: Peeters 2009) or H. Klein, Das Lukasevangelium (KEK; Göttingen: Vandenhoeck \& Ruprecht 2006):

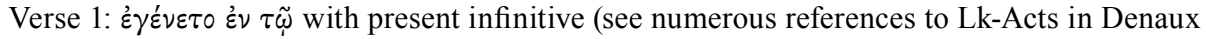
- Corstjens, 124); '̇ $\gamma^{\varepsilon} \nu \varepsilon \tau 0 ~ \dot{\varepsilon} \nu ~ \tau \tilde{\omega}$ with present infinitive + crowd, see 3,21 (Klein, 205, n. 9);

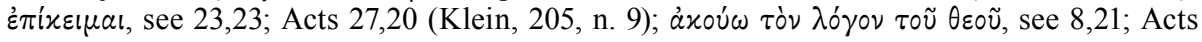
13,7.44 (Klein, 205, n. 9; Denaux - Corstjens, 23); xai aủ đós after description of circumstances, see 5,17; 8,1.22; 9,51; 17,11 (Klein, 205, n. 9); the periphrastic construction $\tilde{\eta} \nu$ with aorist/perfect/present participle, see 1,7.10.21 (Klein, 205, n. 9; numerous other references to Lk-Acts in 
conclude that 5:1-11 is a Lukan composition with Markan influence traceable only in the first three and last two verses of the pericope. ${ }^{20} \mathrm{An}$ important observation that should accompany this conclusion is that the thoroughly Lukan style of 1-3 and 10-11 does not preclude the use of sources. Markan parallels, though heavily reworked, are claimed to be the source of inspiration for the Lukan redaction of the exposition and the conclusion of the story.

The arguments for the former, that is, for a single source behind both the epiphany and the call are to be found in another type of consideration, namely, the discussion of the relationship between Luke 5:1-11 and John 21.

Eleven points of similarity and seven points of difference have been noted between the Lucan and Johannine accounts. ${ }^{21}$ Since there are only two signi-

Denaux - Corstjens, 186); $\dot{\eta} \lambda \dot{i} \mu \nu \eta$, see 8,22f.33 (Klein, 205, n. 9). Verse 2: xai with finite verb

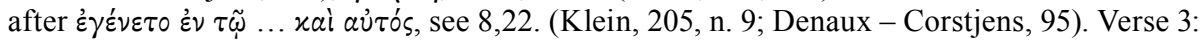

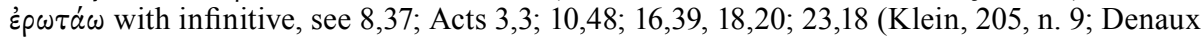
- Corstjens, 251). Verse 4: $\dot{\omega} \varsigma \delta \varepsilon ́$ (see numerous references to Lk-Acts in Denaux - Corstjens, 653; Klein, 205, n. 10); $\pi \alpha \dot{\omega} \omega$ with participle, see Acts 5,42; 6,13; 13,10; 20,31; 21,32 (the first two with the participle of the verb of speaking) (Klein, 205, n. 10; Denaux - Corstjens, 491). Verse 5: $\dot{\pi} \pi$ $\sigma \tau \dot{\tau} \tau \eta$ s, see 5,5; 8,24.45; 9,33.49; 17,13 (Klein, 208, n. 33; Denaux - Corstjens,

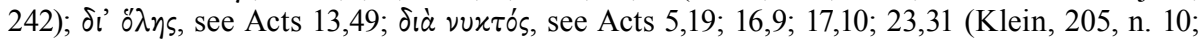
Denaux - Corstjens, 145); $\dot{\rho} \tilde{\mu} \mu \alpha$ as word of announcement, see 1,38; 2,29; 9,45; 18,34 (Klein, 205, n. 10); $\chi \alpha \lambda \alpha^{\prime} \omega$, see Acts 9,25; 27,17.30 (Klein, 205, n. 10; Denaux - Corstjens, 638). Verse 6: $\pi \lambda \tilde{\eta} \theta 0 \varsigma+\pi \circ \lambda u ́$, see 6,17; 23,27; Acts 14,1 (Klein, 205, n. 10; Denaux - Corstjens, 508);

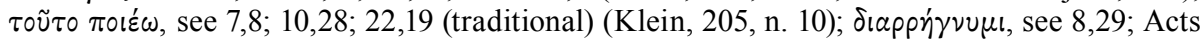
14,14 (Klein, 205, n. 10). Verse 7: Verb of intention + $\tau 0 \tilde{v}$ with infinitive, see 1,9 (Klein, 205,

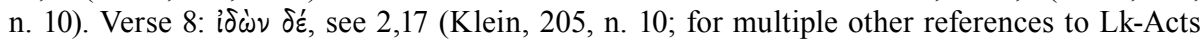

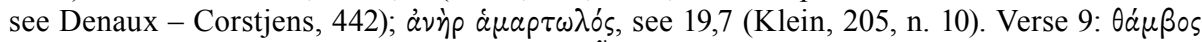

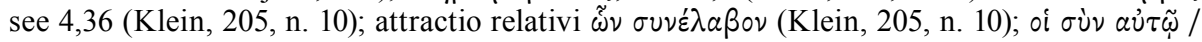

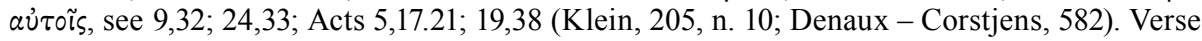

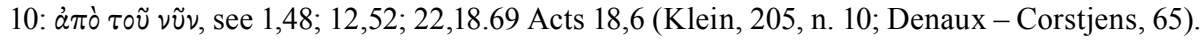

20 See footnote 11.

21 Fitzmyer, following and expanding Brown, The Gospel According to John, 1090, gives the following list of similarities: "(1) disciples who fished all night and caught nothing; (2) Jesus' directive to cast the net(s) for a catch; (3) the directive followed yields an extraordinary haul of fish; (4) its effect on the net(s); (5) Simon Peter reacts to the haul (a clearly Johannine touch makes the Beloved Disciple precede him); (6) Jesus is addressed as 'Lord'; (7) other fishermen take part in the haul, but say nothing; (8) the 'following' of Jesus occurs at the end (see John 21,19. 22); (9) the haul of fish symbolizes a successful missionary endeavor (more explicitly in Luke); (10) the same words used for getting aboard, landing, net, etc. are probably coincidental; but the use of 'Simon Peter' (Luke 5,8; John 21,7) is not-it occurs only here in Luke. One might also add: (11) the absence of any mention of Andrew in either account (cf. Mark 1,16)." Fitzmyer, Luke, I, 560-561.

The differences, as listed by Fitzmyer following A. Plummer, A Critical and Exegetical Commentary on the Gospel According to S. Luke (Edinburgh: T \& T Clark 1896) 147, are: "(1) in John Jesus is not recognized at first; (2) in John Jesus is on shore, not in a boat; (3) in John Simon Peter and the Beloved Disciple are in the same boat; (4) in John Peter leaves the hauling of the fish to others; (5) in John the net is not torn, in Luke it is breaking; (6) in John the fish are caught close to shore and dragged to it; and (7) in John Peter rushes through the water to the Lord, whom he has recently denied; in Luke he begs the Lord to depart from him.” Fitzmyer, Luke, I, 561. 


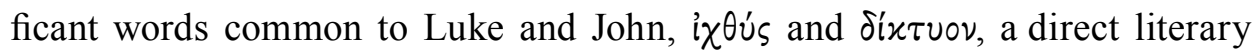
dependence of one account on the other must be excluded. ${ }^{22}$ What remains as the most likely ground of connection between Luke and John is a common tradition going back to either pre- or post-resurrection setting. The argument that the admission of sinfulness on the part of Peter (Lk 5:8) is more at home in the post-resurrection context (after Peter's denial of Jesus) ${ }^{23}$ is countered by the fact that the same admission is an integral part of the epiphany scene resulting in the call of the disciples. The argument that the name Simon Peter is more at home in Johannine tradition ${ }^{24}$ does not resolve the question of whether that tradition was originally connected with pre- or post-resurrection appearance of Jesus. Similarities between the post-resurrection and pre-resurrection fishing miracle suggest that it was the repetition of the pre-resurrection miracle that functioned as the basis for the recognition of the Lord in the post-resurrection setting. ${ }^{25}$ On the other hand, the argument that there are no parallels for projecting pre-resurrection stories into a post-resurrection setting, while it is more common to see retrojection of post-resurrection scenes into the ministry of Jesus ${ }^{26}$ favors the Johannine context as more original. For some, finally, the fact that there already is a tradition, recorded by Mark, which preserves the story of the calling of Peter without any connection to the fishing miracle, militates against the Lukan setting of the epiphany leading to the call of Peter. ${ }^{27}$ As can be seen, the arguments for the original Lukan or Johannine setting to the story are inconclusive. Even the claim that behind both accounts there could only be one historical event is hypothetical. What can be said, however, is that even if the comparison between Luke 5:1-11 and John 21 remains inconclusive as to the identification of the original setting of the story, the fact that similar stories are reported in two different gospels strengthens the suggestion that an early Christian tradition knew of the miraculous catch through which Jesus called

22 J.A. Bailey, The Traditions Common to the Gospels of Luke and John (NT.S 7; Leiden: Brill

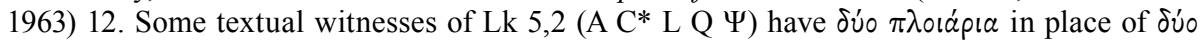
$\pi \lambda$ ĩ $a$ (supported by $\mathrm{P}^{75} \aleph \mathrm{C}^{3} \mathrm{D} \Theta$ ). Such readings add another word in common, namely, $\pi \lambda$ oı́́p ıov used in John 21:8. Even this additional agreement is not enough to posit a literary dependence. Although, see Eckey, Lukasevangelium, I, 242 who accepts the assumption that "der Autor von Joh 21 den lukanischen Text gekannt hat."

23 Fitzmyer, Luke, I, 561-562; Bailey, Luke and John, 14; Sabourin, Luc, 144.

24 Bailey, Luke and John, 14. The name Simon Peter appears in John 21,2.3.11.15, plus numerous occurrences in the rest of John. Lk 5,8 is the only occurrence in Luke.

25 Nolland, Luke, I, 220; Eckey, Lukasevangelium, I, 242.

26 Fitzmyer, Luke, I, 561; Sabourin, Luc, 144. Although, see a cautionary observation by P. Perkins, Peter: Apostle for the Whole Church (Minneapolis: Fortress 2000) 23: "Modern scholars are often quick to spot post-Resurrection influences in all the nature miracle stories because that relieves the demand for a realistic account of 'what happened' to give rise to such a story."

27 Sabourin, Luc, 144; Bailey, Luke and John, 16. 
or reinstituted Peter ${ }^{28}$ Is it possible that it was Luke who created this tradition in the first place? There are at least three elements within Lukan narration that tend to speak against the idea.

Many commentators agree that the use of the double name Simon Peter in $5: 8$ betrays the use of a source. ${ }^{29}$ First of all, this is the only occurrence of the form $\Sigma^{\prime} \mu \omega \nu$ Пźtpos in Luke. Secondly, the narrator who first introduced Simon simply as $\Sigma^{\prime} \mu \omega \nu$ in 4:38 does not explain the meaning of the nickname Пв́трos until the choosing of the twelve Apostles in 6:14. This inconsistency is further evidenced by the fact that in the same story in which the double name appears, the narrator quickly returns to calling the fisherman by his single name Simon (5:10).

Two other arguments refer to less conspicuous phenomena. In describing the lakeside location of the scene, Luke departs from the Markan parallel and, instead of calling the lake the Sea of Galilee ( $\theta \dot{\alpha} \lambda \alpha \sigma \sigma \alpha \tau \tilde{\eta}_{S} \Gamma \alpha \lambda \iota \lambda \alpha i a \varsigma$ Mk 1:16),

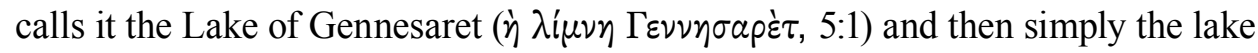

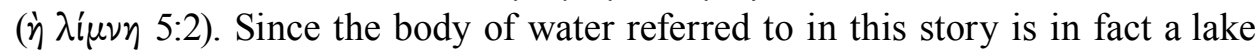
and not a sea, it is sometimes argued that Luke simply corrects the Markan term and calls the lake by what it technically is, a body of freshwater. ${ }^{30}$ In fact, from the writings of Josephus (War 3,463) we know that the topographical designation Gennesar agrees with the way those living in the region referred to the lake. ${ }^{31}$ Luke then appears to give a more accurate geographical description. A recent study of the early Christian topographical tradition in reference to the Sea of Galilee suggests that more might be at stake in Lukan choice of $\lambda i$ i $\mu \nu \eta$ than just a simple correction of the Markan Vorlage. Notley has argued that the name

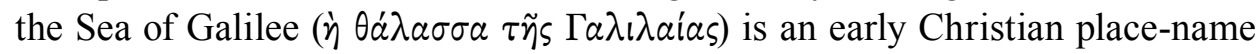
created for the sake of depicting Jesus' ministry in the region of the Lake of

28 E. Arens, "El destinatario del evangelio de Lucas", Revista Bíblica 60 (1998) 225-243, argues for Ephesus as the location of the addressees of Luke's gospel. Arens bases his argument on the special role the city of Ephesus plays in the Book of Acts. The fact that at some point in history Ephesus became associated with both Luke and John strengthens the possibility that the addressees of Luke's gospel would have been familiar with some form of the same Peter tradition that gave rise to John 21.

29 Fitzmyer, Luke, I, 567; Bailey, Luke and John, 14; for Rossé, Luca, 173, n. 19 “esso proviene probabilmente dal racconto prelucano"; for Bock, Luke, I 458, n. 20, "the uniqueness of the phrase speaks to its originality"; for Nolland, Luke, I, 222 it is "probably from the source." Klein, Lukasevangelium, 205 admits that, with some probability, the double name is the only element in the pericope foreign to Lukan style.

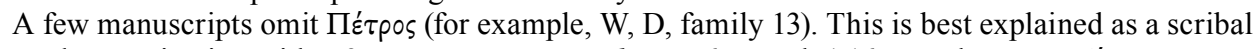
harmonization with 5,3.5; see FITZMYER, Luke, I, 567. Mark 1,16 uses the name $\Sigma$ í $\mu \omega \nu$.

30 Marshall, Luke, 201; Rossé, Luca, 171, n. 12; E.F.F. Bishop, "Jesus and the Lake", CBQ 13/4 (1951) 398.

31 According to R.S. Notley, "The Sea of Galilee. Development of an Early Christian Toponym", $J B L 128 / 1$ (2009) 184, there are numerous references to the lake in the writings of Josephus. All of them call it $\lambda^{\prime} \mid \mu \nu \eta$ rather than $\theta \dot{\alpha} \lambda \alpha \sigma \sigma \alpha$. 
Gennesaret as a fulfillment of Isa 8:23. ${ }^{32}$ It is a topographical tradition common to Matthew, Mark and John. Luke remains independent from that tradition. He exhibits an exclusive use of $\lambda_{i}^{\prime} \mu \nu \eta$ for the lake and in triple tradition narratives he either omits $\theta \dot{\alpha} \lambda \alpha \sigma \sigma \alpha$ or corrects it to $\lambda^{\prime} \mu \nu \eta{ }^{33}$. Since Luke is not known for his geographical precision and since $\lambda^{\prime}(\mu \nu \eta$ is found rather infrequently in LXX (five times in comparison to 432 occurrences of $\theta \dot{\alpha} \lambda \alpha \sigma \sigma \alpha$ ), the best way to explain Luke's omission of the name Sea of Galilee is by postulating sources other than Luke's synoptic counterparts. ${ }^{34}$ Otherwise, as Notley observes, "it is difficult to explain how Luke could derive the geographical framework for his narrative from Mark or Matthew, while consistently and inexplicably omitting their key terminology." 35 This suggestion, of course, refers to Lukan topography as such and not necessarily to every single story of which that topography is a part. But it does open a possibility that the first three Lukan verses of the call of Peter reflect a source independent from references to the Sea of Galilee gleaned from Mark.

One more element of Lukan narration invites our attention. Timothy Wiarda has analyzed various characterizations of Peter in the Gospels and discovered a recurring trait. Wiarda calls it a pattern of reversal. It happens whenever Peter's well-intentioned actions either fail or cause negative reactions, such as correction or rebuke. ${ }^{36}$ Furthermore, since the pattern of reversal is not only well attested but also embarrassing and discontinuous with the prominent image of Peter in the early Church, it is Wiarda's claim that "the reversal motif and the trait-clusters which make up a significant part of Peter's characterization in the Gospels do reflect something of his actual character and experience." ${ }^{37}$ In the Lukan portrayal of Peter, there is only one instance where the reversal pattern

32 Notley, "The Sea of Galilee", 186. A possible attestation to the origin of this Christian toponym is seen in Mt 4,12b-16. Early Christians would have collapsed three geographical indications

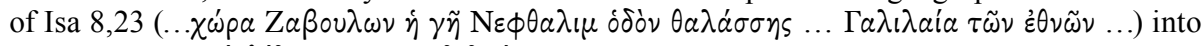
one place-name, $\dot{\eta} \theta \dot{\alpha} \lambda \alpha \sigma \sigma \alpha \tau \tilde{\eta} \varsigma \Gamma \alpha \lambda \iota \lambda \alpha i a \varsigma$, and then depicted Jesus' activity as centered around that place.

33 Mt 4:18-22//Mk 1:16-20=Lk 5:1-11; Mt 8:23-27//Mk 4:35-41 = Lk 8:22-25; Mt 8:28-34//Mk 5:1-20 $=$ Lk 8:26-39; Mt 13:1//Mk 4:1 = Lk 8:4; cf. Mk 2:13= Lk 5:27; Mk 3:7 = Lk 6:17. See Notley, "The Sea of Galilee", 185. In addition to the frequent use of the new toponym, Mark's description of Jesus' journey to the north in 7,31 seems to be based on the structure provided by Isa 8,23. Luke has omitted that material. See Notley, "The Sea of Galilee", 187.

34 Notley, "The Sea of Galilee", 188.

35 Notley, "The Sea of Galilee", 188.

36 See twelve "instances which are fairly obvious according to widely accepted interpretations of the episodes in which they occur:" Mk 8:31-33; 9:5-7; 14:29-30; 14:54.66-72; Mt 14:28-31; Lk 5:8-11; John 13:6-7; 13:8; 13:9-10; 18:10-11; 21:15b-16a; 21:16b-17a; Wiarda, Peter in the Gospels, 36-38. For the list of instances in which the pattern is more faintly present, or in which the pattern becomes apparent when adjoining narrative sections are seen in close connection, see $38-40$.

37 Wiarda, Peter in the Gospels, 226. 
can be detected: Peter's confession of sinfulness and separation from Jesus (verse 8 ) meets with correction and assurance (verse 10b). It is significant that out of twelve fairly obvious instances of the reversal pattern in the Gospels, only one can be found in Luke and that this single instance unique to Luke is at the heart of the calling of Peter in 5:1-11. It strengthens the impression that in redacting the story of Jesus' call of Peter Luke drew on an earlier Christian tradition that kept alive the memory of Peter's actual character and experience. By the same token it weakens the idea that behind 5:8-11 one can only find Lukan creativity and the Markan saying about becoming fishers of men.

Could Luke have used the Markan saying about the fishers to create an Isaiah 6-like vocation scene? Yes, it is possible. But the cumulative weight of arguments presented above pushes the probability toward a single source containing the fishing miracle and the call of Peter, a source which Luke would have reworked but not invented. It could be that Luke harmonized this source with certain elements from Mark, detectable in verses 1-3.10a.11. The parallels with Markan texts mentioned above, as well as the fact that in the Gospel narrative Luke places the call of Peter and his companions as equivalent to the call of disciples depicted by Mark in Mk 1:16-20, suggest such a possibility. Nevertheless, Dietrich's attempt to demonstrate that there are features of 5:1-3 which are difficult to explain on the basis of Mark alone, ${ }^{38}$ as well as his argument for the pre-Markan character of the mention of Zebedee's sons in 5:10a ${ }^{39}$ caution against too quick a dismissal of any non-Markan sources behind 1-3.10a.11.

In conclusion, from the many hypotheses presented, we consider as more probable than others the theory which claims that (1) in composing the story of the call of Peter, Luke relied on a source which depicted the call in connection with the fishing miracle, and (2) in redacting this source, Luke might have used some elements of the parallel story in Mark.

\section{Questions of Historicity}

There remains of course the troubling issue of the competing version of Peter's call in the Gospel of Mark. Can both accounts, Markan and Lukan, have a basis

38 Dietrich, Das Petrusbild, 25-38.

39 Dietrich, Das Petrusbild, 63-76. Dietrich bases his argument on a difference between $\mu \varepsilon ́ \tau 0 \chi 05$

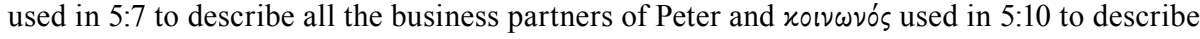
John and James only. His argument might not be strong enough to support the entire weight of the conclusion about the pre-Markan tradition, which would have brought together in a special relation Peter, John, and James. It also has to contend with a certain clumsiness of style with which the mention of Zebedee's sons in 10a follows after the summary in verse 9. 
in history? The fact that Luke replaces the Markan account with a new story would indicate that, in Luke's mind at least, both stories refer to the same event. But if that were the case, then only one of those two diverse stories could claim to reflect a historical event. Before any judgment is passed on the historicity of Peter's call, either in its Markan or Lukan version, two more observations need to be made.

Pheme Perkins has wisely noted that the relationship between Peter and Jesus "involved several turning points." ${ }^{40}$ Lk 22:31-34 and John 21 are among the best-known references to Peter's second birth as a disciple. ${ }^{41}$ John 1:40-42 is an alternative version of his very first transformative encounter with Jesus. If Peter's actual relationship with Jesus was marked by several new beginnings, there could have been several traditions reflecting the (renewed) call(s) of Peter. Such a possibility cannot be excluded especially when one notes how, in the unfolding of Luke's narration, the Call of Peter in 5:1-11 does not stand for the very first encounter but rather follows upon prior interaction between Jesus and Peter in Capernaum (cf. 4:38). ${ }^{42}$

Another possibility presents itself when the oral character of the early transmission of the Jesus tradition is taken into account. Using Byrskog's notion of reoralization, ${ }^{43}$ that is, assuming the situation where "the sources were never objectified entities to be reproduced passively but were constantly reoralized and integrated into participatory, living sociorhetorical discourses about the past, ${ }^{, 44}$ one can argue that the same past event, namely, the one represented in Lk 5:1-11, could have been reoralized in a brief and skeletal form echoed now in Mk 1:16-20. In other words, in a rhetorical setting that required a singular focus on efficacy of Jesus' command and immediacy of the disciples' response, only selected elements of the past would be represented.

40 P. Perkins, "Peter: How a Flawed Disciple Became Jesus' Successor on Earth," Bible Review 20/1 (2004) 23. Perkins lists them: "A young man left his fishing along with his brother; one or more years later, he finds himself called back to the task by the risen Jesus; a Jerusalem ministry followed by a sudden departure and finally the martyr's death."

41 Bockmuehl, Simon Peter, 153-163, retraces the motif of Peter's repentance and rebirth in early Christian literature and art, including its possible echo in 1 Peter 1:3.

42 Another interpretation of the temporal relation between Peter's appearance in Lk 4,38 and his calling in Lk 5:1-11 is also possible. According to F.Ó Fearghail, The Introduction to Luke-Acts: A Study of the Role of Lk 1,1-4,44 in the Composition of Luke's Two-Volume Work (AnBib 126; Rome: Editrice Pontificio Istituto Biblico 1991) 38, "the unit 4,14-44 does not narrate the 'beginning' of Jesus' ministry but represents an anticipation of that ministry which does not stand in a chronological relationship with what follows."

43 Byrskog, Story as History, 138-144.

44 S. Byrskog, "History or Story in Acts - A Middle Way? The 'We' Passages, Historical Intertexture, and Oral History", 266, Contextualizing Acts: Lukan Narrative and Greco-Roman Discourse (ed. T. Penner - C. Vander Stichele) (SBL Symposium Series 20; Atlanta: SBL 2003). 
The fact that a given portrayal of Peter is embedded in and thus shaped by a specific rhetorical orientation of discourse about the past, becomes particularly illuminating when one considers Peter's role in the Gospel of Mark. As Richard Bauckham has shown, ${ }^{45}$ Mark focuses on Peter's role as a disciple, and not on his dominant role in the early Christian community after the resurrection, something other Gospels do (Matt 16:13-19; Lk 22:31-32; John 21:4-19). Naturally, Mark's narrow focus on Peter as a disciple corresponds to Mark's narrow focus on Jesus as the crucified messiah and the kind of discipleship that his messianic identity entails. This peculiar shape of Markan Christology would if not explain then at least be congruent with the selective focus of Mark's version of the call of Peter: an apparent lack of any rationale for Peter's decision to follow Jesus points to Jesus' sovereign authority, the same authority with which the cross is posited rather than argumentatively explained. ${ }^{46}$ On this reading, one would rather speak of the Markan selective abbreviation than the Lukan elaboration of the same account. Mark's brevity would result from his theological concerns, not from his supposed closeness to the original account.

\section{Conclusions}

The historical reconstructions listed above - multiple turning points in Peter's life variously narrativized in different Gospels, Mark's selective abbreviation of the fishing miracle call story, or post-Resurrection origin of the account remain within the realm of possibility. As such, they testify to the limitations of our historical knowledge. Still, the difficulty in establishing a single historical reconstruction of Peter's call should not be too quickly relieved by recourse to literary inventions of the Gospel writers. The Lukan version of the Call of Simon Peter, even though reflective of Luke's narrative interest and bearing marks of his literary style, is not necessarily a fictional embellishment of Mark's austere original. The findings of some recent studies on Peter and the Lake of Galilee tip the balance of probability towards the Lukan use of a source that depicts the call of Peter in connection with the fishing miracle. While historical certainty continues to elude us, the insights generated by recent studies on eyewitness

45 Bauckham, Jesus and the Eyewitnesses, 170.

46 This redactional rationale does not exclude other possible influences on Mark. As noted by Perkins, Peter, 28, Mark could have patterned his story after that in 1 Kings 19:19-21, where a disciple is told to abandon his profession in order to assume a new mission. Similarly, Markan emphasis on pairs of brothers could reflect the early church practice of sending out pairs of missionaries. 
testimony, memory and orality point to new possibilities for understanding the past differently narrativized by Luke and Mark.

\section{Bibliography}

Abogunrin, S.O., "The Three Variant Accounts of Peter's Call. A Critical and Theological Examination of the Texts", New Testament Studies 31 (1985) 587-602.

Adams, H., The Sinner in Luke (The Evangelical Theological Society Monograph Series; Eugene, OR: Pickwick 2008).

Arens, E., "El destinatario del evangelio de Lucas", Revista Bíblica 60 (1998) 225-243.

Bailey, J.A., The Traditions Common to the Gospels of Luke and John (NT.S 7; Leiden: Brill 1963).

Bauckham, R.J., Jesus and the Eyewitnesses: The Gospel as Eyewitness Testimony (Grand Rapids, MI - Cambridge, U.K.: Eerdmans 2006).

Bishop, E.F.F., "Jesus and the Lake", Catholic Biblical Quarterly 13/4 (1951) 398-414.

Bock, D.L., Luke (BECNT; Grand Rapids, MI: Baker 1994) I.

Bockmuehl, M., Simon Peter in Scripture and Memory (Grand Rapids, NI: Baker Academic 2012).

Bockmuehl, M., The Remembered Peter: In Ancient Reception and Modern Debate (WUNT 262; Tübingen: Mohr Siebeck 2010).

Bond, H.K. - Hurtado L.W., eds., Peter in Early Christianity (Grand Rapids, MI: Eerdmans 2015).

Bovon, F., Luke 1: A Commentary on the Gospel of Luke 1:1-9:50 (transl. C.M. THomas) (Hermeneia; Minneapolis, MN: Fortress Press 2002).

Brown, R.E. -Donfried, K.P. - Reumann, J., eds., Peter in the New Testament: A Collaborative Assessment by Protestant and Roman Catholic Scholars (New York: Augsburg Publishing House 1973).

Brown, R.E., The Gospel According to John (XIII-XXI): Introduction, Translation, and Notes (AncB 29A; New York: Doubleday 1970).

Busse, U., "Begegnung mit dem Wort nach Lk 5,1-11", Luke and his readers: Festschrift A. Denaux (ed. R. Bieringer - G. van Belle - J. Verheyden) (Leuven: Peeters 2005).

Byrskog, S., "History or Story in Acts - A Middle Way? The 'We' Passages, Historical Intertexture, and Oral History", Contextualizing Acts: Lukan Narrative and Greco-Roman Discourse (ed. T. Penner - C. Vander Stichele) (SBL Symposium Series 20; Atlanta: SBL 2003) 257-283.

Byrskog, S., Story as History. History as Story: The Gospel Tradition in the Context of Ancient Oral History (WUNT II 123; Tübingen: Mohr Siebeck 2000).

Delorme, J., "Luc 5,1-11: analyse structurale et histoire de la redaction", New Testament Studies 18 (1972) 331-350.

Denaux, A. - Corstjens, R., The Vocabulary of Luke: An Alphabetical Presentation and a Survey of Characteristic and Noteworthy Words and Word Groups in Luke's Gospel (Leuven: Peeters 2009).

Dietrich, W., Das Petrusbild der Lukanischen Schriften (BWANT 94; Stuttgart: Verlag W. Kohlhammer 1972).

Dunn, J.D.G., Jesus Remembered. Christianity in the Making (Grand Rapids, MI - Cambridge, U.K.: Eerdmans 2003).

Eckey, W., Das Lukasevangelium unter Berücksichtigung seiner Parallelen. Teilband 1: Lk 1,1-10,42 (2. durchgesehene Auflage) (Neukirchen-Vluyn: Nuekirchener 2006). 
Fitzmyer, J.A., The Gospel According to Luke I-IX. Introduction, Translation, and Notes (AncB 28; New York: Doubleday 1981).

Grethlein J. - Krebs, C.B., "The Historian's Plupast: Introductory Remarks on Its Forms and Functions", Time and Narrative in Ancient Historiography: The 'Plupast' from Herodotus to Appian (ed. J. Grethlein and C. B. Krebs) (Cambridge: Cambridge University Press 2012) 1-16.

Hengel, M., Saint Peter: The Underestimated Apostle (transl. T.H. Trapp) (Grand Rapids, MI: Eerdmans 2010).

Klein, H., Das Lukasevangelium (KEK; Göttingen: Vandenhoeck \& Ruprecht 2006).

Marshall, I.H., The Gospel of Luke. A Commentary on the Greek Text (NIGTC; Grand Rapids, MI: Eerdmans 1978).

Mathieu, Y., La figure de Pierre dans l'oeuvre de Luc. (Évangile et Actes des Apôtres) une approche synchronique (Études bibliques. Nouvelle série, 052; Paris: Gabalda 2004).

Mciver, R.K., "Eyewitnesses as Guarantors of the Accuracy of the Gospel Traditions in the Light of Psychological Research", Journal of Biblical Literature 131 (2012) 529-546.

Militsios, N., The Shaping of Narrative in Polybius (Berlin - Boston: Walter de Gruyter 2013).

Neale, D., None but the Sinners: Religious Categories in the Gospel of Luke (JSNT.S 58; Sheffield: Academic Press 1991).

Nolland, J.L., Luke 1-9:20 (WBC 35a; Dallas: Word Books 1989).

Notley, R.S., "The Sea of Galilee. Development of an Early Christian Toponym”, Journal of Biblical Literature 128/1 (2009) 183-188.

Ó Fearghail, F., The Introduction to Luke-Acts: A St udy of the Rol e of Lk 1,1-4,44 in the Composition of Luke's Two-Volume Work (AnBib 126; Rome: Editrice Pontificio Istituto Biblico 1991).

Perkins, P., "Peter: How a Flawed Disciple Became Jesus' Successor on Earth," Bible Review 20/1 (2004) 12-23.

Perkins, P., Peter: Apostle for the Whole Church (Minneapolis: Fortress 2000).

Pesch, R., Der reiche Fischfang: Lk 5,1-11/Jo 21,1-14. Wundergeschichte - Berufungserzählung - Erscheinungsbericht (Kommentare und Beiträge zum Alten und Neuen Testament; Düsseldorf: Patmos 1969).

Pesonen, A., Luke, the Friend of Sinners (Diss. University of Helsinki; Helsinki 2009).

Plummer, A., A Critical and Exegetical Commentary on the Gospel According to S. Luke (Edinburgh: T \& T Clark 1896).

Radl, W., Das Evangelium nach Lukas. Kommentar. Erster Teil: 1,1-9,50 (Freiburg im Breisgau: Herder 2003).

Redman, J., "How Accurate Are Eyewitnesses? Bauckham and the Eyewitnesses in the Light of Psychological Research", Journal of Biblical Literature 129 (2010) 177-197.

Rossé, G., Il Vangelo di Luca. Commento esegetico e teologico (Collana Scritturistica di Città Nuova; Roma: Città Nuova 1992).

Sabourin, L., L'Évangile de Luc. Introduction et commentaire (Roma: Pontificia Universitas Gregoriana 1985).

Schmidt, D.D., "Rhetorical Influences and Genre: Luke's Preface", Jesus and the Heritage of Israel: Luke's Narrative Claim upon Israel's Legacy (ed. D.P. Moessner) (Harrisburg, PA: Trinity Press International 1999) 27-60.

Schneider, G., Das Evangelium nach Lukas. Kapitel 1-10 (ÖTNT 3/1; Gütersloher - Würzburg: Gütersloher Verlagshaus 1977).

Scholz, D.J., Luke 5:1-11: The Call and Commission of Simon Peter (Diss. Marquette University; Milwaukee, WI 1997). 
Schröter, J., "The Gospels as Eyewitness Testimony? A Critical Examination of Richard Bauckham's Jesus and the Eyewitnesses", Journal for the Study of the New Testament 31.2 (2008) 195-209.

Schürmann, H., Das Lukasevangelium. I. Kommentar zu Kap. 1,1-9,50 (HThKNT 3; Freiburg: Herder 1969).

Wiarda, T., Peter in the Gospels: Pattern, Personality, Relationship (WUNT II 123; Tübingen: Mohr Siebeck 2000).

Wolter, M., Das Lukasevangelium (HNT 5; Tübingen: Mohr Siebeck 2008). 